\title{
Study of Existing Problems and Countermeasures of Agricultural Product Export Trade in Shanxi
}

\author{
Zhou Zhou \\ Economic and Trade Department, Xijing University, Xi'an Shaanxi, 710123, China
}

Keywords: Agricultural product export trade, Problem location, Countermeasure study.

\begin{abstract}
The process of economic globalization drives agricultural internationalization. With constant enhancement of our international influence, relation of agricultural products domestic and overseas becomes closer. Our agricultural products entering into international market could not only promote our international competitiveness but also effectively enhance peasant income level, advancing construction of socialism new countryside and further shaking off poverty in rural areas. Shanxi is our big agricultural province in the west area, whose agricultural product trade occupies a big proportion in national economic aggregate. Under the new situation of economic development, enhancing international competitiveness of Shanxi agricultural exports is of great significance to drive the development of Shanxi agricultural products international trade and construction of socialism new countryside. This article is to analyze the existing problems in Shanxi agricultural products export trade and propose countermeasures according to the current international and domestic development situation, hoping to help the development of Shanxi agricultural products export trade.
\end{abstract}

\section{Introduction}

The reform and opening-up policy drives the development of economic society. Under such background, Shanxi agricultural development appears good situation. The supply and demand of agricultural products could realize balance, some of them generating constitutive property surplus, gross volume of export increasing remarkably ${ }^{[1]}$, and overall agricultural productivity gradually upgrading. However, there are still very severe problems during development. Shanxi agricultural products export is limited both by resource supply and market requirement. As for the big agricultural province with abundant agricultural resources, manpower resource and scientific and technological resources, how would Shanxi solve the difficulty of agricultural products export has been paid attention by the public. Thus, this article hopes to further analyze the facing problems and explores the scientific solution, providing helpful suggestions for Shanxi agricultural products export.

\section{Existing Problems in Shaanxi Agricultural Products Export Trade}

\section{Increasingly severe technical barrier}

The current world economic development tends to be integration and international trade appears liberalization. WTO strictly prohibits trade protectionism. Since the Uruguay Round, each member state in WTO has sharply reduced import tariff of agricultural products and repealed quantitative limitation. But the trade protection phenomena still generally exist in developed countries, which are all transferred to technical barriers and keep increasing. The trade environment of agricultural products is not optimistic. As one of our main export countries, Japan implements "positive list system” which seriously affect export economic benefit of Shanxi agricultural products.

The attention to technical barriers keeps changing, from production and processing to planting and cultivation. Since this transition of our export products, pesticide residue problem has obviously become the chronic disease for our agricultural products export and enriching food safety supervision and management could admit of no delay ${ }^{[2]}$. 


\section{Sharply enhanced operating cost}

In recent years, the sharply enhanced operating cost becomes the dilemma for many agricultural product export enterprises. Firstly, as the labor concentrated industry, labor resource shortage and bigger labor cost increase enterprises' operating burden. Secondly, the rise of strategic materials prices such as farm-oriented materials, petroleum, etc. and the improvement of agricultural products plantation and transportation cost result in substantial appreciation of agricultural products raw materials prices and big shock to enterprises. Thirdly, trade barrier make more proving time for clearance and export inspection cost. For example, after the implementation of positive list system, the domestic and Japanese clearance time is extended to half a month, making enterprises facing big pressure of goods and capital turnover. Finally, in order to reach the food safety standard made by import country, relevant enterprises of Shanxi agricultural products export should inevitably inspect the farm chemical indexes of agricultural products and spend more scientific research funds and equipment investment.

\section{Enterprises lacking core competitiveness}

Shanxi is our big province of agricultural products export, but the enterprises still lack core competitiveness and thus are hard to get advantages in international competitions. Major performances are low scientific and technological level and irregular quality. From the aspect of product level, most export products are primary. Enterprises haven't established their own brands and thus the added value of products is very low. From the processing stage, it is mainly rough machining, with rough processing and packaging, which could hardly meet the consumer demand of high quality life in import countries. Key emphasis in work of many cities and counties in Shanxi to adjust agricultural structure is still to add numbers. But the explore market and coordinating production and marketing has become their short slabs, which cause such problems as low quality, lacking brands, etc. It is hard to promote international competitiveness; on the contrary, it would enhance operating cost and intensify disparities between supply and demand, damaging the enterprises' images to some extent. For example, some areas in Shanxi could plant apples, but the export proportion is not big. The reason to such phenomenon is that there is no classification to apples and thus hard to promote total income by classification sale.

\section{Not enough domestic and overseas market development}

Shanxi agricultural product export countries are relatively centralized, mainly the close countries. Thus, once the import policies in those countries change, it would affect the Shanxi agricultural products export. For example, the "positive list system" pushed out by Japan is very severe test standard. After the technical standard is enhanced, the agricultural products export to Japan faces big dilemma.

\section{Traditional agricultural production problems impeding export scale}

At present, though agriculture industrialization gains considerable performance, enterprises of agricultural product export are always with small scale and decentralized operation, which impede the alliance and upgrading of export enterprises. The study data shows that till the end of 2015, total quantity of Shanxi agricultural product export enterprises has reached a certain scale. But by analyzing the total export of each enterprise, the leading enterprise plays an important role in driving Shanxi total value of export, while the average value of exports is not pleasant. Analysis shows that there are several reasons that export enterprises are hard to realize scale operation: firstly, the scale of enterprise is too small, with weak strength, low organizational degree and weak ability to resist export trading market risk and trade barrier. Secondly, the development of many agricultural products enterprises adopts extension road, whose scale and living example can not be equal to transnational agricultural products enterprises with foreign capital. Thirdly, agricultural products enterprises are mostly with small scale, lower threshold and too rapid speed of number of the enterprises, which cause market competition disorder and cut down the overall efficiency of export enterprises ${ }^{[3]}$. 


\section{Countermeasure to the Development of agricultural product export trade in Shanxi}

In recent years, Shanxi agricultural products export is influenced by many domestic and international factors. In China, the raw materials price and labor cost keep rising which cause soaring of enterprises operating cost. In international, people's attentions to food safety improve continually, and increase the protection to domestic agriculture with more severe technical barrier. Facing such situation, it should drive the healthy development of Shanxi agricultural products export from the following aspects.

\section{To perfect agricultural product export policy}

Referring to the domestic and overseas experience to drive agricultural development, it needs to establish and perfect strategic measures to support Shanxi agricultural products export. Firstly, it should enhance financial support to the whole provincial agricultural product export enterprise, set a special fund, major support those leading enterprises and demonstration base enterprises with powerful leading role, drive them to construct export bases, export base deep processing of agricultural products, prolong industry chain to export agricultural products, strengthen alliance between giants enterprises and promote core competitiveness of Shanxi agricultural products export enterprises. Secondly, the banks should support the development of agricultural products export enterprises by credit funds, build commercial bank and cooperative mechanism to cooperative mechanism enterprises, increase loan commitment, simplify handling procedures and broaden terms of credit. It should make use of financing function of special project guarantee fund in small import and export enterprises. According to the creditworthiness of import and export enterprises of agricultural products and stability of export channel, it could consider to set the export special purpose loan by financing institutions to solve farmers' problems of turnover of capital. Thirdly, with relevant fund, it should subsidize those export enterprises to join in such propaganda as brand construction, foreign trademark registration, etc. to perfect export credit premium subsidy measure and promote export enterprises' ability to resist risks. At last, it should promote agricultural product export inspection and quarantine and clearance service level, simplify inspection and quarantine procedures to those guaranteed agricultural products, lower charges and guarantee priority clearance.

\section{To expand market area of agricultural product export}

Under the premise of guarantee the current agricultural product export market, it should expand burgeoning sales market, build omnibearing, multilevel and stratification agricultural product export market structure. As for the actual demand of export countries, it should carry out further study to guarantee the supply of agricultural products meeting market demand and make different market expanding plans to different areas and countries. For example, to the enterprises targeting in Japan, they should regulate and control the production and export of agricultural products according to the agricultural products standard and market demand changes in positive list system. In detail, they need to increase export proportion of cooked food, reduce fresh food export and increase exploitation of agricultural products. Enterprise with exportable agricultural products should cooperate with relevant departments, such as department in charge of market development, institution functioning abroad of Commerce Department, etc. to increase generalization of high quality agricultural products. They should also fully use internet to reinforce publicity and communication with overseas distributors, cultivate trade talents of agricultural product export and meet the demands to expand overseas market.

\section{To promote agricultural exports realizing industrial upgrading}

On the basis of play our advantages of traditional agricultural products export, it should strive to develop emerging industry, such as flower industry and form the development situation of both together going. As for the emerging industry, the development key is the fine processing products with higher fine processing products and additional values so as to enhance benefit of unit agricultural product. Promoting brand concept should not only develop each territorial brand in the 
province but also push out characteristic brand, keeping a foothold of regional reality, reinforcing authentication construction of geographical indications and promoting the general figure of Shanxi agricultural products. They could seek the support of commercial department, carry out brand publicity in emerging market, exploit approach to overseas generalization, promote agricultural exports enterprises to apply for domestic and overseas trademark registration, enhance their international popularity and change the extensive business model of agricultural exports enterprises fundamentally. They should create conditions to optimize the integrated development environment, intensify policies support and protect enterprise brand.

\section{To cultivate leading enterprise of agricultural product export}

The agricultural industrialized operation is not only the overall development tendency in current agriculture in China but also the important way to promote international competitiveness. The features of industrialized operation lie in high enterprises enterprise, flexible system and mechanism. And the key of industrialized operation of agricultural product export enterprises is to motivate the enthusiasm of leading enterprise. Thus it should increase support to those enterprises with bigger export scale, leading technological level, longer industrial chain and higher overall management efficiency so as to organically integrate their resources and realize maximize of profits. Accommodation ability of leading enterprise should be improved to promote reasonable expansion, adopt many schemes to guarantee turnover of enterprises funds and promote banks to improve credit aid to agricultural product export enterprises ${ }^{[4]}$. It should also broaden financing channel and carry out economic and technological cooperation with foreign countries.

\section{To advance the implementation of international standard of agricultural products export}

It is to introduce international or key export regions' quality safety of agricultural products and on this basis, build quality standard to production and detection of Shanxi agricultural products exports, enhance measurement technique, make detection procedures standard and guarantee the quality of agricultural exports fundamentally. As for the sale in domestic market, it should also pay attention to quality and establish good fame in China. It needs to keep under strict supervision to the use of chemicals in agricultural products, reduce pesticide residue, build and perfect detection and service center and drive checkout equipment to realize resource sharing.

\section{To enhance the construction of demonstration area for quality safety of agricultural products export}

It should perfect institution-building of demonstration area, clear separation of duties, carry out collaboration, labor for national supportive policy to the agricultural product export enterprises, increase financial support to the construction of demonstration area, establish working system in risk management of demonstration area, enhance coping capacity to emergency circumstances, strengthen information communication of each department and form the linkage mechanism ${ }^{[5]}$. To make scientific supervisory goal, quantizing quality safe index, promoting scientific running of quality control system and perfecting quality evaluation index system.

\section{Conclusion}

As our big province of agricultural product export, Shanxi faces many problems in the current agricultural product export trade, including more serious technical barrier, sharply enhanced operating cost, lacking core competitiveness, not enough domestic market development, not forming scale management in agricultural product export enterprises. As for these, this article proposes some countermeasures, such as perfecting agricultural product export policies, expanding market area, promoting industrial upgrading, cultivating leading enterprise, advancing the implementation of international standard to agricultural product export and enhancing demonstration area construction for quality safety of agricultural products. With relevant departments' collaborative cooperation, 
problems faced by Shanxi agricultural products export would be readily solved and the agricultural products export trade would welcome brand new situation.

\section{References}

[1] Wan Liping, Developmental Feature and Existing Problems of Agricultural Product Export Trade from China to America, Modern Economic Information, 2015(12): 180-180, 198.

[2] Yang Bosong, On the Existing Problems and Solutions to Agricultural Product Export, Inner Mongolia Coal Economy, 2015(12):58-59.

[3] Ding Dandan, Existing Problems Analysis and Countermeasures Study of Chinese Agricultural Products Export Trade, Market Modernization, 2015(14):2-2.

[4] Chen Ping, Price Setting and Supportive Policy Study of Chinese Agricultural Products Export Trade, Prices Monthly, 2015(5):14-16.

[5] Zhang Wenhu, Long-term Strategy for Chinese Agricultural Products Export Trade, Nongjia Guwen, 2015(4):30. 